\title{
Influence of Socio-Cultural Aspects on the Production of Main Speech Acts in Mohammed Mahdi Al-Jawahiri's Poem 'O Sir! Inspire $m e^{\prime}$ \\ https://doi.org/10.33806/ijaes2000.21.1.2
}

\author{
Musaab A. Raheem Al-Khazaali \\ Hussein Dhahi Muzhir \\ Hussam Rashid H. Jarullah \\ University of Kufa, Iraq
}

\begin{abstract}
This paper tackles how speech acts offer deep insights into the social structure in poetic text. Most relevant research on poetic speech acts has shed much light on Western speech and literature, neglecting the speech act behavior of Arabic literature, particularly poetry. This study aimed to treat the effect of cultural aspects on the production of main speech acts in Al-Jawahiri's masterpiece 'O Sir! Inspire Me'. Relying on Searle's classification of main speech acts and the findings of analysis, the results show that the poet Al-Jawahiri utilizes more representative and expressive speech acts in his poem to enhance that what he presents is a fact to be believed concerning the praise and description of the king, His Majesty Hussein bin Talal, on the one hand, and his heartfelt love and emotion towards the king, on the other. This is also accompanied by the findings that there is an association between the socio-cultural aspects and the production of speech acts in poetic texts. Islam, Arabism and prestigious ancestry are factors that have been found to play an important role in defining the cultural norms of the production of main speech acts in the poem under scrutiny.
\end{abstract}

Keywords: main speech acts, poetic text, Searle's taxonomy, socio-cultural aspects.

\section{Introduction}

The current paper tackles the effect of cultural aspects on the production of main speech acts in Al-Jawahiri's masterpiece ' O Sir! Inspire Me'. Most relevant research on poetic speech acts has shed much light on Western speech, and literature, neglecting the speech act behavior of Arabic literature, particularly poetry. This study starts from a standpoint that Arabic poetry is full of cultural constructions in the formulation and invocation of speech acts. As such, this study stands itself to bridge this gap in previous studies.

Mohammad Mahdi Al-Jawahiri, an Iraqi poet born in 1899, is the most famous Arab poet in the $20^{\text {th }}$ century who represents the peak of Arabic Classicism and poeticity where he was assigned by many critics the nickname 'The Greatest Arab Poet'. His poem 'O Sir! Inspire Me' in which he praises His Hashemite Majesty the late Jordanian Monarch ' King Hussain bin Talal' on his birthday in 1992 is selected as the data of analysis to achieve the aims of the study. 


\subsection{Objectives}

The current study attempts to achieve the following aims:

1. To find out the most frequent types of speech acts in Al-Jawahiri's poem ' O Sir! Inspire Me'.

2. To highlight the influence of cultural aspects on the speech acts production in Al-Jawahiri's poem ' O Sir! Inspire Me'.

To achieve the aims of the study, the researchers attempted to recover the contextual features (mainly the socio-cultural ones) of these speech acts and see if the elements of sincerity and loyalty are felicitously reflected by the linguistic and socio-cultural signs used for performing the speech acts in the poem under scrutiny.

\section{Theoretical background}

The study of the relationship between culture and speech act production is viewed as part of what is called 'sociopragmatics'. Sociopragmatics is related to how our sociocultural knowledge influences our interaction (Leech 1983: 130). For Crystal (1998), it is the study of the social backgrounds of the participants in an interaction and it looks at the way in which factors (like sex, age, power, religion, ethnic origin ...etc.) affect people's choice of linguistic patterns or forms. The main standpoint of the current paper is that cultural aspects formulate and affect our ways of producing speech acts in a variety of contexts including literary ones. The paper starts with a general overview of the relationship between culture and communication as well as the main classification of speech acts and their conditions.

Culture is highly related to language use and communication. The analysis of meaning (including pragmatic meaning) consists in " a serial contexualization of our facts, context within context, each one being a function, an organ of the bigger context and all contexts finding a place in what might be called the context of culture" (Firth, 1957: 1940). Thus, linguistic acts cannot be fully interpreted without being related to or contexualized in a particular culture (Lyons 1977: 609). Hence, speech acts may be viewed as a reflection of specific cultural aspects and conceptions such as 'social identity'. Cognitively speaking, our linguistic understandings of linguistic messages are represented by mental efforts to formulate and construct our meanings through compromising social world and discursive world to make our own perceptions of what we see and receive in our cognitive world. Barrett (2006) highlights this supposition when he argues that linguistic signs (words/sentences/speech acts) are indexically employed when they are manipulated to achieve the context of occurrence, i.e., they are "indexicals to create social contexts... [communication] involves the projection of particular speaker identities and stances and the establishment of social relationships between participants. The contextual functions of an indexical are inseparable from its expressive and phatic functions" (p. 168). As such, language can be used to emphasize intergroup identities. It can reproduce social and psychological connections in different or similar ethnic and religious groups. Such group identities are said to be salient. Therefore, speakers attempt to highlight or 'construct' their membership in a socio-cultural group via language or discourse (Eelen 2001: 216; Meyerhoff 2011: 73). Identity is generated through culture - especially language - 
and it can invest itself in various meanings: an individual can have an identity as "a woman, a Briton, a Black, a Muslim. Herein lies the facility of identity politics: it is dynamic, contested, and complex" (Harrison 1998: 248). According to TabouretKeller (1997: 315), "language acts are acts of identity". He identified four key areas of identity research - self-identity, collective identity, institutional identity and global identity. It is also established that people and organizations possess multiple identities on the basis of the multiple roles they are capable of fulfilling or representing in the socio-cultural relationships in which they participate.

In the same vein, according to Fuller (2007: 105, 107), social identity is defined as the socially constructed membership in a social group or category. As such, social identity is not that aspect which is determined by factors [such as ethnicity, sex, age,...etc.], but that aspect which is constructed through discourse. Gumperz (1982) previously argues that there are no universal felicity conditions or appropriateness principles in production and perception of communicative and interactive acts. Rules of speaking as they apply to speech events, have shown that language usage, norms "for what counts as appropriate speech behavior, as well as the very definitions of such events vary from culture to culture and context to context" (p. 3). Similarly, He (1982) suggests that interactive constant synchrony requires "some degree of predictability and routinization, such as is most commonly acquired by shared culture and similarity of interactive experience)" (p. 141). Although, distinctions among such activities as gossiping, debating and lecturing exist in almost all cultures, "but each culture has its own constraints not only on content but also on the ways in which particular activities are carried out and signaled" (Gumperz 1982: 166). And even in the same culture, each individual will view each activity in the light of his/her background knowledge and contextual circumstances. Felicity conditions, as adopted in this study, provide the appropriate circumstances for the application of different pragmatic or interactive acts. The basic felicity conditions in any speech act are:

1. Propositional content condition. Searle (1969) sees that the propositional content involves that the performative utterance components should fulfill the performed act.

2. Preparatory condition. Searle (1980: 322- 323) claims that the preparatory condition of performative utterances means that these utterances have clear purposes behind uttering them. For example, we cannot say that we are ordering someone to do something, when it is obvious that this person is already doing or is about to do this action.

3. Sincerity condition. Sincerity condition involves that both speakers and hearers tend to do the desired speech act correctly. For instance, Searle (1980: 323) claims that the sincerity condition for the act of 'promising' implies that the speaker should intend to do the act. In representatives, sincerity condition can be envisioned as the speakers' genuine belief of what is asserted.

4. Essential condition. Searle (1980: 323) explains that the essential condition in performing speech acts requires the commitment of speakers and hearers to do the actions which are expressed by their utterances. 
All in all, felicity conditions are a framework for the combination of appropriateness of utterance content, intentions and overall context in which that utterance is produced.

\section{Method}

\subsection{Sample and Context}

The sample to be analyzed is represented by the poem $O$ Sir! inspire $m e^{l}$. The great poet Mohammed Mahdi Al-Jawahiri composed this improvised poem which was delivered in front of His Majesty, the Hashemite King Hussain bin Talal, in Amman on the $2^{\text {nd }}$ of December, 1992.The Iraqi poet in his poem attempts to describe and praise the great king with a focus on the cultural and historical attributes and deeds of the monarch of Jordan, the Arab Muslim country. These aspects will be the focus of the socio-cultural analysis of the speech acts utilized in the poem.

\subsection{Instruments}

The instrument of analysis will be the main aspects of speech act, focusing on the definition and classification of the main speech acts. A speech act is defined as an act performed by a speaker in saying something (with an appropriate intention and in an appropriate context), rather than by virtue of having produced a particular effect by saying something. For instance, if someone says 'I order you to leave now' , s/he has performed the act of ordering, simply by virtue of having uttered the words, whether or not the addressee acts in the desired way (Cruse 2006: 167-168).

Searle (1976) develops Austin's (1962) taxonomy of speech acts as follows: 1. Representatives. Like Austin's constatives, representatives have a truth value: They "commit the speaker to something's being the case, to the truth of the expressed proposition ... The direction of fit is words to the world; the psychological state expressed is Belief (that p) " (Searle 1976: 10). Thus, acts of 'asserting', 'reporting', 'stating', 'concluding', 'deducing', and 'describing' are paradigmatic cases of representatives. Sentence (1) illustrates this type:

(1) Barack H. Obama is the forty-fourth President of the United States.

2. Directives. The illocutionary point of directives is that they are attempts ... by the speaker to get the hearer to do something ... The direction of fit is world-to-words and the sincerity condition is want (or wish or desire). The propositional content is always that the hearer ... does some future action" (Searle 1976: 11). Acts of 'requesting', 'asking', 'ordering', 'commanding', 'begging', 'pleading', 'praying', 'defying' and 'challenging' are paradigmatic cases of directives. Sentence (2) illustrates this type:

(2) Give me the salt.

3. Commissives. They are "illocutionary acts whose point is to commit the speaker... to some future course of action ... The direction of fit is world-to-words and the sincerity condition is Intention. The propositional content is always that the speaker ... does some future action ... " (Searle 1976: 11). Acts of 'promising', 'threatening', 'offering' and 'pledging' are exemplary cases of commissives. Sentence (3) illustrates this type:

(3) I will have written this paper by Friday next week. 
4. Expressives. "The illocutionary point of this class is to express the psychological state specified in the sincerity condition about a state of affairs specified in the propositional contents ... in expressives there is no direction of fit" (Searle 1976: 12). The gist of expressives is that they express the speaker's psychological attitude or state, like joy, grief, sorrow, etc. Acts of 'thanking', 'congratulating', 'apologizing', 'condoling', 'deploring' and 'welcoming' are paradigmatic cases of expressives. Instance (4) illustrates this type:

(4) What a wonderful paper, Mark!

5. Declarations. Searle points out that they "are a very special category of speech acts". Declaratives "bring about some alternation to the status or condition of the referred-to object or objects solely in virtue of the fact that the declaration has been successfully performed". However, the successful performance of declarations requires the existence of an extra-linguistic institution in which the speaker and the hearer occupy special places. "The direction of fit is both words-to-world and world-to-words ... there is no sincerity condition" (Searle 1976: 14). Paradigmatic cases of declarations are successful acts of 'appointing', 'nominating', 'marrying', 'christening', 'excommunicating', 'declaring war', 'resigning', and 'firing (from employment)'. Example (5) illustrates this type:

(5) I now pronounce you Man and Wife.

Relating speech acts to their socio-cultural context in which they are used, Seuren (2009: 147) emphasizes that all speech acts ... are performative in that they create a socially binding relation or state of affairs ... "[T]he primary function of language is not 'communication', in the sense of a transfer of information about the world, but social binding, that is, the creation of specific interpersonal, socially binding relations with regard to the proposition expressed by an utterance or speech act". Such kind of social connectivity or binding is a vital factor in the social textile that is an essential pre-requisite for human communication in all its aspects that constitute what is called ' speech community'.

\subsection{Data analysis and results}

The analysis is composed of two basic methods: pragmatic analysis of the main speech acts used in the poem and their relation to the socio-cultural aspects in which they are used and statistical analysis of the most frequent speech acts employed in the poem and their value in relation to socio-cultural aspects and the intended message of the poet. The following are some illustrative examples of each class of speech acts:

1. Representatives (Assertives): These acts are used to get the receiver to form a belief and, as such, would be appropriate for identity construction and maintenance. It expresses the sender's belief in something that can be evaluated as true or false. Representatives speech acts are found in a variety of other acts or contexts such as suggestions, swearings, and conclusions. The poet used such assertives to show the origin of the king as a fact to be believed by listeners and to praise the king for his elevated deeds for people in different times and places, as in the following examples: 


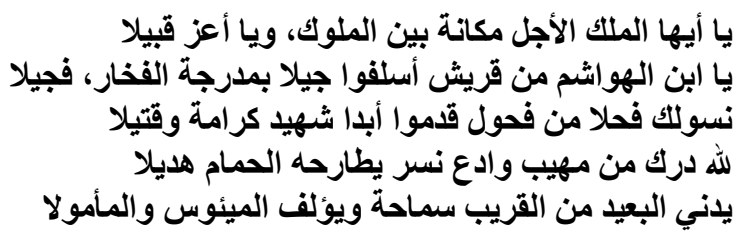

(O, you are the most reverend king amongst all kings,

And has descended from the most honourable tribe.

O the son of the Hashemites of Quraish,

Those who passed down glory through generations.

You have descended a virile man of men who forever sacrifice martyrs or killed for dignity.

God bless you of a man, meek though majestic.

Like an eagle flirting with the cooing of doves.

Lenient to unite who is distant with the nigh

And turn what is desperate back to hopeful..)

Al-Jawahiri utilized different tools and strategies in his assertions such as

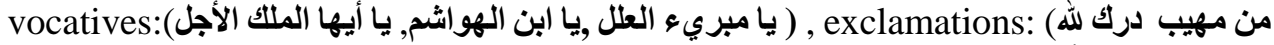

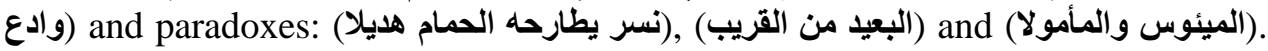
All these strategies are deployed to enhance the message of the poet to praise and describe the unique attributes of the great king.

Swearing or oath is a kind of representatives which are employed by the poet Al-Jawahiri to emphasize what he believes to be true and to convince listeners to believe in what he says:

$$
\begin{aligned}
& \text { قسما بمن أولاك أفضل نعمة من شعبك التمجيد والتأهيلا } \\
& \text { إني شَيت بمجد قربك ساعة من لهفة القلب المشوق غليلا }
\end{aligned}
$$

(I swear by He Who's bestowed upon you the best blessing, glorification and appreciation by your people,

I've been cured, by being close to you for an hour, of my yearning heart's eagerness.)

Here, the poet's speech acts of representatives are felicitous as far as their sincerity conditions are concerned. As such, the poet has been sincere and loyal to his Majesty, the King, in that the latter's features are sincerely presented and reflected as real beliefs and truths. Such representations are apparently indicated by the king's highly prestigious origin and ancestry.

2. Directives: This class of main speech acts occurs when the writer asks the receiver to do something (e.g., a command, a plea). For example, the speaker may make a request, ask a question, or issue an invitation or invocation. Al-Jawahiri starts his poem with a basic directive, a plea, in which he asks the king to aid his mouth to say sweet and good things about him: 


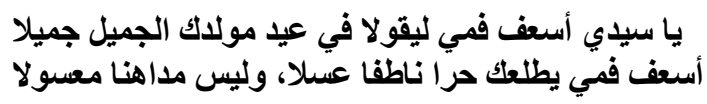

(O Sir! Inspire me to say sweet words on your beautiful birthday. Aid my tongue to release the sweet of overflowing honey-like talk, Not sweetened buttery talk.)

He also seems to use more supplications and invocations for Allah to save and lengthen the age of the great king:

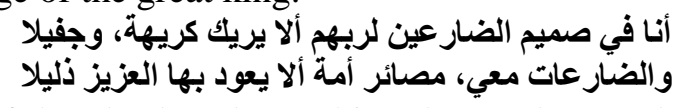

(I am in the core of the pleaders, beseeching the Lord not to let you in misfortune and distress.

With my prayers, the destinies of a nation plead that the esteemed one would not be humiliated.)

Also, he uses indirect invocations by assertions, as in:

$$
\text { يا مبرئ العلل الجسام بطبه تأبي المروعة أن تكون عليلا }
$$

(O healer of incurable diseases with his treatment! Virility rejects that you be ill.)

3. Expressives: This class of main speech acts occurs in utterances when a speaker or writer expresses his/her psychological state to the hearer/reader. Typical cases are when the speaker greets, complains, apologizes, or thanks to the audience. In other words, this act expresses feelings toward (though not essentially about) the receiver. It also involves acts such as congratulations, condolences, compliment and gratitude. It should be confirmed that expressives can be indicated by different indirect speech act such as questions and assertions. Al-Jawahiri employs many expressive speech acts to express his emotions and feelings towards the king to confirm his love, loyalty and hope. Instance can be presented as follows:

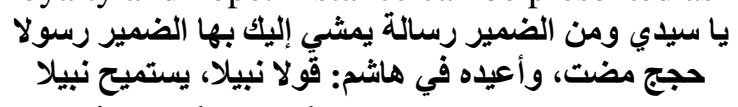

(O Sir! It is from conscience that we have a messagewith which, the conscience will hastily walk to you.

Years have passed and in Hashem I recur it, a noble saying pleading a nobleman.)

Here, the poet attempts to express what is found in his conscience which is the centre of feelings and passion. Another sense of love can be viewed in the following instance where he expresses his love towards the king's grandfathers which is not courtesy but a religious duty on all Muslims:

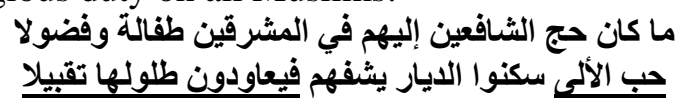

(The pilgrimage of the patrons to them in the East was not childish and curious.

The love of those who lived in the house heals them, so they came back kissing their ruins.)

4. Commissives: This class of speech acts occurs when speaker/writer commits to a future course of action such as promising, threatening, planning, and betting. The essential aim of this illocutionary act is to confirm to the receiver that the language user will frankly and honestly perform some action in the future. In his poem, AlJawhiri utilizes the speech act of promise to finish his poem: 


\section{ولسوف تعرف بعدها يا سيدي أني أجازي بالجميل جميلا}

(And then you will surely know, sir, that I repay the one who does me a favour with the good reward.)

5. Declarations: These acts are utterances bringing about a change in the state of affairs. They may include naming, nominating and the like. The poet presents some examples of declarations in which he describes the king with special names such as (مبرئ العلل الجسام):

\section{يا مبرئ العلل الجسام بطبه تأبى المروءة أن تكون عليلا}

(O healer of incurable diseases with his treatment! Virility rejects that you be ill.) Moreover, the poet utilizes assertions to show that the king declares him special status and position:

\section{فوسمتني عزا وكيد حواسد بهما يعز الفاضل المفضولا}

(And you signed me honor which triggers the scheme of the enviers, with them the honorable loved the favourable.)

The content analysis of the statistical percentages of the main speech acts is indicated in the following Table 1.

Table 1. Percentages of main speech acts used in the poem

\begin{tabular}{|l|l|}
\hline Speech act & Percentage \\
\hline Representatives & 41.14 \\
\hline Directives & 30.36 \\
\hline Expressives & 20.47 \\
\hline Commissives & 3.59 \\
\hline Declarations & 2.44 \\
\hline Total & $100 \%$ \\
\hline
\end{tabular}

As the tabulation shows, the most frequent speech acts are representatives (41.14 \%), followed by directives (30.36\%) and expressives (20.47\%). This indicates that the poet intends to utilize these speech acts to enhance the descriptive and praising goal of the poem. The poet manipulates assertives more than other acts to prove that what he says about the king is a kind of facts and real information. These acts are basically formulated in the achievement of sincerity condition in which the poet genuinely reflects his solid beliefs. Moreover, the use of directives and expressives reflects the emotional and passionate atmosphere of the poem. AlJawahiri inclines to express the overflow of his feelings towards the great king of Jordan which implies the love of all people for his personality, achievements and deeds. The amalgamation between facts and emotions implies the talent of AlJawahiri in balancing such differentiated aspects. However, the least frequent speech acts have been commissives $(3.59 \%)$ and declarations $(2.44 \%)$ since they are implemented to end the poem and there are no changes of the reality by such 
poetic speech acts. The use of few acts of this type ensures the poet's loyalty for the king since he has one word to be a promise for the king.

As far as the cultural aspects are concerned, the paper sheds the light on the connections between the socio-cultural aspects and the linguistic behavior represented by the use of speech acts in the poem under scrutiny. Generally speaking, the "cultural norms of a society are always displayed in the rules of speaking in a particular speech community" (Bachrach, Kosinski, Graepel, Kohli and Stillwell 2012). The following aspects are found to be controlling factors in AlJawahiri's poem under study:

1. Arabism and Islam:

It is found out that the Arabic-Islamic social backgrounds play a vital role in the process of constructing speech acts in this poem. It is recognized that such aspects are seen in the poet's applications, supplications and invocations for Allah to save and lengthen the life of the king. Expressive speech acts are also flourished by such religious expressions since they are a direct result of the conspicuous impact of Islam on the speech of Muslims. Arabism and Islam are the two basic origins of culture in the poem since the king is presented as a son of the prophet of Islam, the Arab great leader 'Mohammed' (peace be upon him and his holy progeny). His great fathers are there in the original ground of Arabs 'Hijãz', as follows:

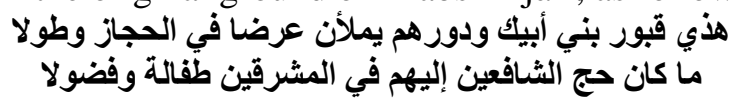

(These are your father's sons graves and homes that extend all over the ground of Hijãz.

The pilgrimage of the patrons to them from the East and the West was neither childish nor curious.)

And also it is found in the following lines:

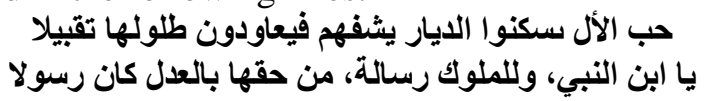

(The love of those who lived in the house heals them, so they came back kissing their ruins.

O son of the Prophet, and kings have a message, he who justly conveyed it, was a messenger.)

The poet praises the great king saying that you are the son of the messenger of God and as people love your fathers and ancestors, they love you now. The results of this study are in line with what was asserted by Altakhaineh, AlTkhayneh, and Rahrouh's (2019) and Banikalef's (2019)studies that speech acts are felicitously produced in the light of the cultural features in the immediate context of communication. Thus, "the different forms of speech acts derive their sociocultural importance not only from their religious background but also from other social, cultural, and political factors" (p.411).

2. Prestigious ancestry:

The great lineage of the king, his Majesty Hussein bin Talal goes back to the golden ancestry of the prophet's Hashemite family. This prestigious and highly appreciated origin controls most of the poem where the poet focuses and re-affirm such great 
lineages in several lines, describing the grandfathers and grandmothers of the king as well as the great achievements and sacrifices for the nation and humanity:

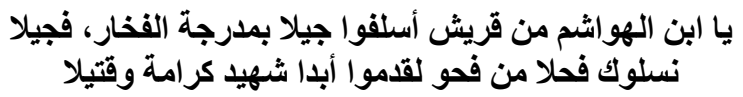

(O the son of the Hashemites of Quraish,

Those who passed down glory through generations.

You have descended a virile man of men who forever sacrifice martyrs or killed for dignity.)

Here, the king is described in terms of his family which is from Quraish and Hashem, the grandfather of the prophet of Islam 'Mohammed' (PBUH). His fathers are the great martyrs of the nation.

Then, the poet mentions some details of the names of the king's grandmothers 'Fatima and Khadijah' as well as his grandfathers 'Aqeel and Hussein', they are those in whose houses the Glorious Qur'an was recited and given to the prophet:

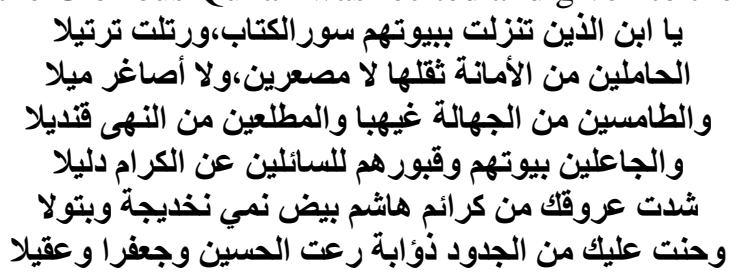

$(\mathrm{O}$, son of those who in their homes,

the scripture verses have been brought down and well recited-

the holders of the weighty trust without being pompous, nor being inclined, for a little bit, away of the Right.

And those who blacked out the gloominess of ignorance, and kindled a lamp out of the wise mind,

and those who made their homes and graves, a guide for the seekers of the noble men's generosity.

Your roots are bound to the high bred daughters of Hashem: Khadijah and Batool who grew pure.

And from the grandfathers, a forelock yearned on you that inherited the attributes Al-Hussein, Jaafr and Aqeel.)

The poet not only inclines to describe the features of the king's ancestors, but he implies, by using such representatives, that the great king Hussein bin Talal has such aspects in his behaviour and personality since he is the legal heir of this great lineage. 


\section{Conclusion}

Relying on Searle's classification of main speech acts and the results of analysis, the data show that the poet Al-Jawahiri intends to utilize more representative and expressive speech acts in his poem to prove that what he presents is a fact to be believed concerning the praise and description of the king, His Majesty Hussein bin Talal, on the one hand, and his heartfelt love and emotion towards the king, on the other. This is also accompanied by the findings that there is an association between the socio-cultural aspects and the production of speech acts in poetic texts. AlJawahiri intelligently connects his poem's cultural atmosphere with the value of tribe and lineage in the Jordanian and Arabian society when he focuses on the great origin of the king's family in the production of main speech acts including representative and expressive ones. The current study proves that poetic speech acts cope with socio-cultural system in which that text is produced. This is clearly evident in the interrelation between speech acts, intention and contextual features in which such acts have been used.

Future studies are supposed to concentrate on a contrastive aspects of English and Arabic poetic texts in the light of the interconnection between cultural aspects and the recognition of speech acts. It is also suggested that future research can shed the light on the role of cultural aspects in the construction of pragmatic coherence between speech acts in literary and poetic texts.

\section{Endnote}

The poem is translated and edited by Emeritus Prof. Dr. Ahmed Shakir AlKilabi (Applied Linguist and Translator) of Al-Kafeel University (E-mail: ahmed.alkilabi@uokufa.edu.iq), Assoc. Prof. Dr. Muslim Abbas Eidan (PhD. in English poetry and Literary Translation),Emeritus of Kufa University (E-mail: dr.muslimeidan@gmail.com), and Dr. Hussain Nasser Al-Ibadi (Applied Linguist and Translator) of Open Educational College (E-mail:hussainalibadi@gmail.com ).

Musaab A. Raheem Al-Khazaali

University of Kufa, Iraq

ORCID Number: 0000-0002-3492-5170

E-mail: musaab.alkhuzaie@uokufa.edu.iq

Hussein Dhahi Muzhir

University of Kufa, Iraq

ORCID Number: 0000-0001-5180-9617

E-mail: husseinmuzhir33@gmail.com

Hussam Rashid H. Jarullah

University of Kufa, Iraq

ORCID Number: 0000-0002-1749-0224

E-mail: hussam.hammood@uokufa.edu.iq 


\section{References}

Altakhaineh, Abdel Rahman, Khawlah Al-Tkhayneh and Hanan Rahrouh. (2019). 'The effect of the gender and culture of the IELTS examiner on the examinees' performance on the IELTS speaking test in the UAE context'. International Journal of Arabic-English Studies, 19 (1): 33-52.

Austin, John. (1962). How to do Things with Words. The William James Lectures Delivered at Harvard University in 1955. Oxford: Clarendon Press.

Bachrach, Bachrach, Michal Kosinski, Thore Graepel, Pushmeet Kohli and David Stillwell. (2012). 'Personality and patterns of Facebook usage'.Proceedings of the 3rd Annual ACM Web Science Conference on WebSci 12: 24-32.

Banikaelf, Ala'Eddin. (2019). 'The Impact of culture and gender on the production of online speech acts among Jordanian Facebook users'. International Journal of Arabic-English Studies, 19 (2): 399-414.

Barrett, Rusty. (2006). 'Language ideology and racial inequality: Competing functions of Spanish in an Anglo-owned American restaurant'. Language in Society, (35): 163-204.

Cruse, Alan. (2006). A Glossary of Semantics and Pragmatics. Edinburgh: Edinburgh University Press.

Crystal, David. (1998). A Dictionary of Linguistics and Phonetics (4th edn.). Oxford: Blackwell Publishers.

Eelen, Gino. (2001). A Critique of Politeness Theories. Manchester: St. Jerome.

Firth, J. R. (1957). Papers in Linguistics. Oxford: Oxford University Press.

Fuller, Janet. (2007). 'Language choice as a means of shaping identity'. Journal of Linguistic Anthropology, 17 (1): 105-129.

Gumperz, John J. (1982). Discourse Strategies. Cambridge: Cambridge University Press.

Harrison, G. (1998), 'Political identities and social struggle in Africa'. In A. J. Kershen (ed.), A Question of Identity, (248-270). Aldershot: Ashgate.

Leech, George N. (1983). Principles of Pragmatics. London: Longman.

Lyons, John. (1977). Semantics (Vol. 2). Cambridge: Cambridge University Press. Meyerhoff, Miriam. (2011). Introducing Sociolinguistics. London: Routledge.

Searle, John R. (1969). Speech Acts: An Essay in the Philosophy of Language. Cambridge: Cambridge University Press.

Searle, John R. (1976). 'A classification of illocutionary acts'. Language in Society 5: $1-23$. 
Searle, John R. (1980). 'What is a speech act?'. In Pugh, A. K. Leech, J. V., \& Swann, J. (eds.), Language and Language Use, (312-327). London: Heirman Educational Book in association with the Open University Press.

Seuren, Pieter A. M. (2009). Language from Within Vol. I.: Language in Cognition. Oxford, UK: Oxford University Press.

Tabouret-Keller, A. (1997), 'Language and identity'. In F. Coulmas (ed.), The Handbook of Sociolinguistics, (315-326). Oxford: Blackwell.

\title{
Appendix
}

\section{The poem and its translation}

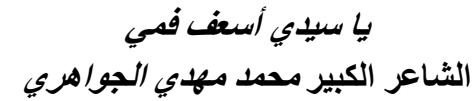

القصيدة المرتجلة بصوت الثاعر أمام صاحب الجلالة الهاشمية الحسين بن طلال المعظم ألقيت

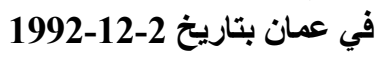

فيما يلي نص القصيدة التي كتبها الثاعر فيما بعد

يا سيدي أسعف فمي ليقو لا في عيد مولدك الجميل جميلا

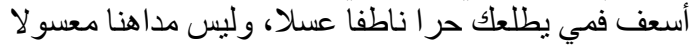

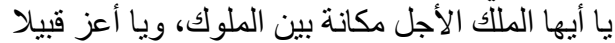

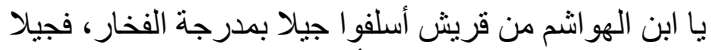

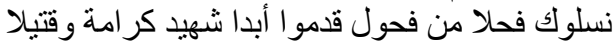

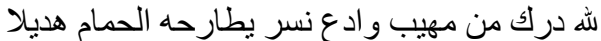

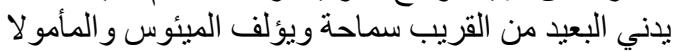

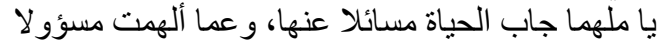

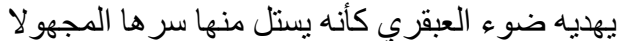

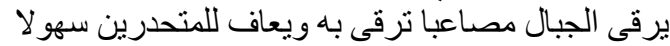

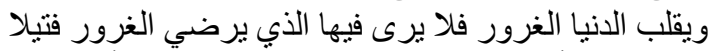

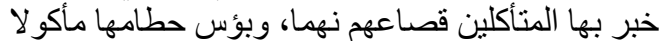

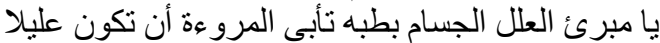

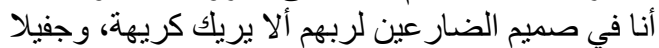

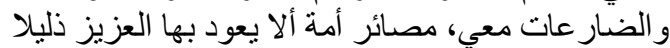

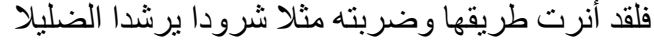

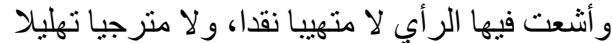

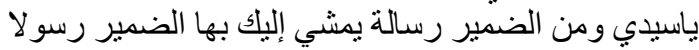

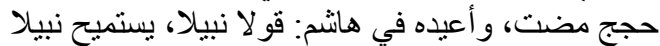

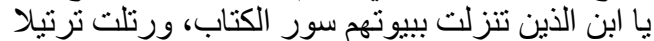

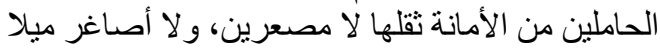

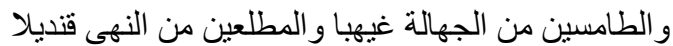

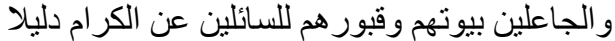

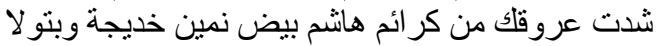

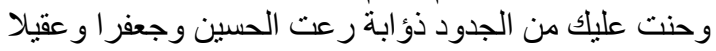




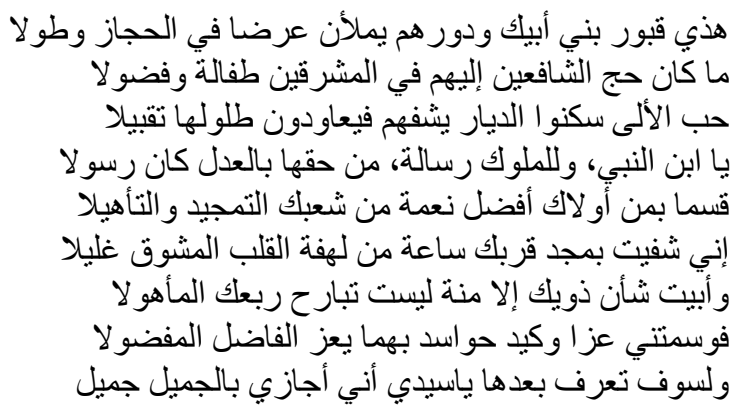

O Sir! inspire me.

The great poet Mohammed Mahdi al-Jawahiri

In the voice of the poet, the improvised poem was delivered in front of His Hashemite Majesty, Hussain ben Talal, in Amman on the $2^{\text {nd }}$ of December, 1992.

The following is the text of the poem later written by the poet.

O Sir! Inspire me to say sweet words on your beautiful birthday.

Aid my tongue to release the sweet of overflowing honey-like talk,

Not sweetened buttery talk.

$\mathrm{O}$, you arethe most reverend king amongst all kings, andhas descended from the most honourable tribe.

O the son of the Hashemites of Quraish,

Those who passed down glory through generations.

You have descended a virile man of men who forever sacrifice martyrs or killed for dignity.

God bless you of a man, meek though majestic ..

Like an eagle flirting with the cooing of doves.

Lenient to unite who is distant with the nigh

And turn what is desperate back to hopeful.

$\mathrm{O}$, you're the inspirer

who roamed around to wonder about life 
and how it inspires you back.

Granted with the lantern of genius

In search of its secrets.

Climbing over mountains of hardships, rising high, Away from the unambitious drifting down.

You looked over the world, with hope of 'lofty soul', But undeceived a bit by its vanity fair.

Of it, he is all- knowing its gluttonous eaters and the misery of its eaten wreckage. O healer of incurable diseases with his treatment! Virility rejects that you be ill. I am in the core of the pleaders, beseeching the Lord not to let you in misfortune and distress.

With my prayers, the destinies of a nation plead that the esteemed one would not be humiliated.

You have illuminated its way and struck him,

An example of a fugue guiding the delusion

And in it you spread attitude, neither fearing criticism nor hoping acclamation.

O Sir! It is from conscience that we have a message-

with which, the conscience will hastily walk to you.

Years have passed and in Hashem I recur it, a noble saying pleading a nobleman.

O, son of those who in their homes,

the scripture verses have been brought down and well recited-

the holders of the weighty trust without being pompous, nor being inclined, for a little bit, away of the Right.

And those who blacked out the gloominess of ignorance, and kindled a lamp out of the wise mind, 
and those who made their homes and graves,

a guide for the seekers of the noble men's generosity.

Your roots are bound to the high bred daughters of

Hashem: Khadijah and Batool who grew pure.

And from the grandfathers, a forelock yearned on you that inherited the attributes Al-Hussein, Jaafr and Aqeel.

These are your father's sons graves and homes that extend all over the ground of Hijãz.

The pilgrimage of the patrons to them from the East and the West was neither childish nor curious.

The love of those who lived in the house heals them, so they came back kissing their ruins.

O son of the Prophet, and kings have a message, from their right to justice, he was a messenger.

I swear by He Who's bestowed upon you the best blessing, glorification and appreciation by your people,

I've been cured, by being close to you for an hour, of my yearning heart's eagerness.

And you stayed as your relatives' affairs, except for a gift that not leaving your flourished court.

And you signed me honor which triggers the scheme of the enviers, with them the honorable loved the favourable.

And then you will surely know, sir, that I repay the one who does me a favour with the good reward. 